Meta

Journal des traducteurs

Translators' Journal

\title{
Work Placements in Masters of Translation: Five Case Studies from the University of Western Australia
}

\section{Hélène Jaccomard}

Volume 63, numéro 2, août 2018

URI : https://id.erudit.org/iderudit/1055151ar

DOI : https://doi.org/10.7202/1055151ar

Aller au sommaire du numéro

\section{Éditeur(s)}

Les Presses de l’Université de Montréal

ISSN

0026-0452 (imprimé)

1492-1421 (numérique)

Découvrir la revue

Citer cet article

Jaccomard, H. (2018). Work Placements in Masters of Translation: Five Case Studies from the University of Western Australia. Meta, 63(2), 532-547.

https://doi.org/10.7202/1055151ar
Résumé de l'article

En Australie, les stages forment une composante essentielle de la plupart des diplômes de traduction comme préparation indispensable à l'entrée dans le monde du travail. Toutefois, les stages ne sont pas toujours menés de façon éthique et efficace. Cet article analyse les aspects pragmatiques et théoriques des stages professionnalisants en traduction, en prenant pour exemple cinq stagiaires de l'Université d'Australie occidentale (University of Western Australia). L'expérience de ces étudiants, pour variée qu'elle soit, prouve qu'il faut mettre en place des garde-fous afin d'assurer le succès de la collaboration tripartite - université/stagiaire/hôte. La flexibilité et l'autonomie des étudiants semblent jouer un rôle important dans la réussite de la mise sur pied d'un stage. Le responsable sur le lieu de travail et le coordinateur universitaire doivent être bien préparés à remplir leurs tâches, en s'inspirant éventuellement des systèmes instaurés dans le cadre de stages d'apprentissage. Néanmoins, les étudiants de ces études de cas ont dû faire face à des problèmes que rencontrent et résolvent quotidiennement les traducteurs. Ils sont maintenant mieux préparés à entrer dans le monde du travail. 


\title{
Work Placements in Masters of Translation: Five Case Studies from the University of Western Australia
}

\author{
HÉLÈNE JACCOMARD \\ University of Western Australia, Perth, Australia \\ helene.jaccomard@uwa.edu.au
}

\begin{abstract}
RÉSUMÉ
En Australie, les stages forment une composante essentielle de la plupart des diplômes de traduction comme préparation indispensable à l'entrée dans le monde du travail. Toutefois, les stages ne sont pas toujours menés de façon éthique et efficace. Cet article analyse les aspects pragmatiques et théoriques des stages professionnalisants en traduction, en prenant pour exemple cinq stagiaires de l'Université d'Australie occidentale (University of Western Australia). L'expérience de ces étudiants, pour variée qu'elle soit, prouve qu'il faut mettre en place des garde-fous afin d'assurer le succès de la collaboration tripartite - université/stagiaire/hôte. La flexibilité et l'autonomie des étudiants semblent jouer un rôle important dans la réussite de la mise sur pied d'un stage. Le responsable sur le lieu de travail et le coordinateur universitaire doivent être bien préparés à remplir leurs tâches, en s'inspirant éventuellement des systèmes instaurés dans le cadre de stages d'apprentissage. Néanmoins, les étudiants de ces études de cas ont dû faire face à des problèmes que rencontrent et résolvent quotidiennement les traducteurs. Ils sont maintenant mieux préparés à entrer dans le monde du travail.
\end{abstract}

\begin{abstract}
In Australia work placements are an essential part of most postgraduate qualifications in Translation Studies as a way to guarantee graduates' job-readiness. Work placements, however, are not always run ethically and efficiently. This research paper analyzes the pragmatic and theoretical aspects of professional placements in Translation Studies, and reports on work placements of five Masters students at the University of Western Australia. The students' experiences were diverse and proved that safeguards need to be put in place for work placements to be successful tripartite collaborations between universities, trainees and hosts. Flexibility and students' autonomy seemed to play an important part in the success of work placement arrangements. Both work supervisor and subject coordinator must be properly prepared for their tasks, perhaps taking guidance from their counterparts in vocational studies. Nonetheless, all students in these cases studies were confronted with real-life issues that translators have to routinely solve and this rapidly increased their job-readiness.
\end{abstract}

\section{RESUMEN}

En Australia las prácticas en empresas son parte esencial de la mayoría de las titulaciones de postgrado en Traducción como forma de garantizar la preparación para el empleo de los graduados. Sin embargo, estas prácticas no siempre se realizan de forma ética y eficaz. Este trabajo de investigación analiza los aspectos pragmáticos y teóricos de las prácticas profesionales en Estudios de la Traducción y documenta las prácticas de cinco estudiantes del Master de la Universidad de Western Australia. Las experiencias de los estudiantes fueron variadas y demuestran la necesidad de establecer salvaguardias en las colaboraciones tripartitas entre las universidades, los estudiantes en prácticas y las entidades anfitrionas para que estas prácticas tengan éxito. La autonomía y la flexibilidad 
de los estudiantes parece jugar un papel importante en el éxito de estos acuerdos de prácticas. Tanto el supervisor de trabajo como el coordinador de la asignatura deben estar debidamente preparados para sus tareas, y quizás deban tomar como referencia a sus homólogos en los diplomas de formación profesional. No obstante, todos los estudiantes que aparecen en los estudios de casos se enfrentaron a problemas de la vida real con los que los traductores se enfrentan de manera rutinaria y mejoraron rápidamente su preparación para el mercado laboral.

\section{MOTS-CLÉS/KEYWORDS/PALABRAS CLAVE}

work placement, work-readiness, translation, ethics stages, préparation au monde du travail, traduction, éthique prácticas en empresas, preparación para el empleo, traducción, ética

In the decades following the 1970s turn in Translation which redefined translation as a legitimate studies area (El Maghnougi 2014), the realization that formal degrees in Translation were sorely missing led to the development of new higher education degrees. The pedagogical thinking behind such courses often suffered from a lack of understanding of the outcomes and assessment mechanisms required for these professional degrees. From the 2000s, re-evaluations of courses were conducted (Hubscher-Davidson and Borodo 2012). Such research determined that work placements were an essential component of Translation degrees. French academic Daniel Gouadec (2007: 362) in his spirited call for improvement in, and professional relevance of, university translation courses, drew up a five-point list of essential constituents of any degree, and included an "immersion in real-life working environments - particularly through work placements.”

Work placements cover a range of work-related experiences: volunteering, internships (usually of a longer and more targeted nature than work placements as such), work experience (shadowing, observing professionals), trainee programs (specific roles for long periods of time), and apprenticeships (nationally-sanctioned schemes involving both studies and work). All schemes provide an opportunity for an individual to spend a temporary amount of time within an organization to gain insight and skills relevant to their desired job role or industry, with the aim of helping guide the individual's career choices and giving them a professional head start, with support and guidance from a potential employer. ${ }^{1}$

As a tripartite collaboration, work placements are mutually advantageous to students and hosts. The latter benefit from interns' eagerness and new ideas and represent an ideal opportunity to bridge the university-industry gap (Pym, Gonzalez-Núñez, et al. 2013). Report after report from various stakeholders stress the central importance of Work Integrated Learning (WIL) so as to make students work-ready, a catch cry in today's higher education sector: "Specifically, WIL is aimed at improving the employability of graduates by giving them valuable practical experience which is directly related to courses being studied at university," a report on a comprehensive national strategy asserts by the Australian Collaborative Education Network Limited (ACEN 2015: 1). ${ }^{2}$ The authors also emphasize the benefits for higher education institutions:

For universities, most with decades-long partnerships with employers developing the professional and vocational skills of students, the benefits include ensuring the currency and relevance of the education they provide in an operating environment that has never evolved more rapidly. (ACEN: 2) 
Work placements are a chance for students to apply their theoretical and practical knowledge in authentic settings (Duignan 2003: 336), enhance their academic performance (Duignan), establish close links with practitioners who may be "useful recruitment resource[s]" (Orlando 2012: 201), observe actual workflow and duties, and exercise real-life work ethics. I would add, although it is not mentioned in the literature, that this is also an opportunity for students to find out whether they are good at, and likely to enjoy, their future profession. With these ambitious outcomes in mind it is hardly surprising that, despite national bodies' promises of support, enablers, and capacity building exercises (ACEN 2015: 3), the reality of work placements leaves something to be desired.

Recent research has uncovered many issues in work placements. A negative that is raised for all types of work placements, particularly in a European context where a great deal of Higher Education courses demand long stints of internships, is the risk of exploitation. ${ }^{3}$ In recent years, the British press ${ }^{4,5}$ has reported many instances of exploitation of unpaid interns. French companies, small and large, have been guilty of making graduates work for nothing for months, even years at a time. The scandalous precariousness of interns, no more than "contemporary slaves"6 and "ghost employees" regularly leads to as-yet-unmet demands for a change in the legal status of interns in France. To mitigate such dire revelations, I hasten to note these unethical internships are often not sanctioned by universities and are not part of university courses, but are offered to graduates in search of a position as a way to transition to the workplace. However, a large proportion of such internships never turn into paid jobs. It is not known whether budding translators suffer more from bogus or exploitative internship practices than their counterparts in other professions. We can assume that like other young would-be professionals, they may fall prey to well-documented unscrupulous practices rife in high unemployment, high labor-cost European countries irrespective of the sector of activity.

With regard to university-sanctioned work placements in the translation industry, remarks by British academic John Duignan (2003: 336) on "negative outcomes" of badly supervised placements will resonate with many educators, confirming prior research in terms of a weak integration of theory and practice, inappropriate placements or poor quality of in-house supervision. In the conclusion of his research Duignan emphasizes that a better 'architecture' of the placements would go a long way to improving the outcomes. This is also the conclusion arrived at by Coventry (2016) regarding work placements in general: "what needs to be considered is how to structure internships so they are able to provide mutually beneficial, meaningful and rewarding work." Commenting on eight cases of translation research placements Anthony Pym and his team (2013: 1) propound a structure predicated on long-term preparations prior to placement: "relations of trust" have to be established; "mutual benefits are envisaged; and there are prior arrangements for receiving visiting researchers." Although Pym, Gonzalez-Núñez, et al.'s paper concerns, not translation work but research placements, a fairly undeveloped area, it is safe to assume that its recommendations apply to translation work placements too.

Structure or 'architecture' (Duignan 2003) includes the way the internship fits into the course, its duration, whether it is paid or voluntary, physical and/or virtual. It also sets out the respective responsibilities of the subject coordinator (drafting the contract, preparing and often assessing the intern, ensuring that contractual obliga- 
tions of both trainee and host are met), and the work supervisor (the direct line manager at the office), and their involvement in the pre-translation and post-translation workflow and quality control. As to assessment, the standard practice is for students to write work diaries and reflective reports, collate a portfolio of work done, and for hosts to fill out an evaluation form. ${ }^{8}$ In theory, assessment is supposed to be closely aligned to graduates' academic outcomes. The National report mentioned above (ACEN 2015: 8) also takes the pedagogy of work placements into consideration, in particular "the relevance to curricula requirements (including authenticity, integration of theory and practice, alignment with learning outcomes and assessment)." Marc Orlando (2012) devotes a large section of his research on practicums at Monash University to assessments of translation practicums, whereas Gouadec (2007) in his pragmatic book on the translation profession seems unaware of this academicallyoriented requirement. Rather than assessing the placements as academic exercises Pym, Gonzalez-Núñez, et al. assess success on the basis of cost-benefit analysis for the research student and their host, and "multilevel social exchanges" (Pym, Gonzalez-Núñez, et al. 2013: 17). The structure determines whether the placement is based on a work environment model or a learning environment model (Duignan 2003: 339). In the former the emphasis is on relations with the host and ensuring a good match between them and the student; in the latter, the university "retains an active role in [the] placement experience" (Duignan).

Drawing on translation work placements for students in the second year of their Master of Translation Studies at the University of Western Australia (UWA), I will describe and analyze the placement structure, supervision and assessment in five case studies, and conclude with some recommendations on best practice.

\section{Translation Work Placements, UWA}

Launched in 2014, the Master of Translation Studies at UWA is a two-year postgraduate degree training both from and into English and one of four language specializations: French, Italian, German and Chinese. The Master is approved by Australia's National Accreditation Authority of Translators and Interpreters (NAATI), which, under stringent conditions, allows the university to recommend students for the much-coveted NAATI professional translator's accreditation. In its second year, the Master offers two pathways: by coursework only or by coursework and dissertation. Most students choose the coursework only pathway as they have professional rather than research career plans. Whichever pathway they select they have to undertake a short work placement.

Instructions for translation work placements are kept simple and straightforward so as to give as much flexibility as possible to the working arrangement students are most interested in. This qualifies the UWA translation work placement structure as Duignan's 'work environment model.'

During their first year of studies students have the opportunity to attend events organized with and by practitioners and professional organizations. They also study a unit about Ethics and professional conduct requiring them, amongst other tasks, to interview practitioners in their language stream. The unit naturally revolves around the Code of Ethics ${ }^{9}$ devised by the Australian Institute of Translators and Interpreters (AUSIT) and adopted in the 1990s as the national code of conduct by 
NAATI. Students are given scenarios to discuss amongst themselves and with practitioners so as to apply the code adequately. Aimed at training students to behave professionally during their placements, the unit is also pragmatic in nature so as to prepare students to become NAATI accredited professional translators, whether for a company, an agency or freelance. In the ethics unit, students are therefore introduced to typical translation workflows such as communication with clients, preparations, reviewing, and quality control. Simulated role-plays allow students to understand the array of roles closely connected to the translation sector, such as project manager, terminologist, copy-editor/reviewer, and localiser. Localisation is further developed and practiced in another dedicated unit.

By the time students are ready to do their work experience, they should have built enough professional acumen to find and approach their own host. However, a database of potential hosts is also available to them. The placement consists of 120 hours of work, either full-time over three weeks during summer or winter breaks, or part-time. Students keep a diary using online Blackboard's Journal function and submit a reflective analysis at the end of the placement, while the host provides an evaluation sheet and comments on the intern. For reasons of business confidentiality, no portfolio of work is provided or assessed.

The work placements have to be face-to-face, either in Western Australia, other Australian states, or overseas. One student proposed a virtual work placement in Hong-Kong, but this was deemed unsuitable as she would not be involved in the daily office routine, not exposed to dealings with clients and work-flows, nor immersed in another culture and working environment. Nonetheless, a paper published in 2010 claims that virtual work placements match linguistic and recruitment benefits of physical placements, whilst reducing the financial burden of transnational placements (Vriens, Op de Beeck, et al. 2010). Virtual placements have their role, if only as a not-for-degree opportunity for professional development. Provided there is a personal connection between the work and the subject coordinators prior to the placement so as to institute good feedback protocols, virtual placements could be considered when physical placements are not an option. The research papers' authors encourage higher education providers to consider blended models - both physical and virtual - for maximum efficiency. UWA could consider such blending on a case-by-case basis in the future.

The flexibility of the work placement arrangement at UWA is also important in a place as isolated as Perth, Western Australia. The geographical context cannot be underestimated in terms of placements and job prospects for translators. Pym, Gonzalez-Núñez, et al. (2013) too found that contextual matters such as distance from centres of decision had an impact on the availability and success of research placements.

Western Australia economy relies on a fairly narrow base of mineral and agricultural commodities, most of them exported to China. Revenue from education and tourism has grown in recent years, with again a large share generated by Chinese people. Employment prospects are therefore closely associated with China and its economic strength. The Perth chapter of the Australia-China Business Council ${ }^{10}$ boasts 180 members, all major Chinese businesses and corporations. The Western Australian Chinese Chamber of Commerce established 20 years ago covers China and South-East Asia; most of its members are small- and medium-sized companies. 
A Chinese speaking newspaper, Australian Chinese Times, was founded 30 years ago, and the oldest Chinese community association in Australia, Chung Wah, dating back to 1909 is located in Western Australia.

Most of the dozen or so Translation and Interpreting agencies have Chinese staff on their books, some UWA's own freshly graduated translators. The need for university-trained translators is recognized by local and national professional associations such as the AUSIT and the Western Australian Institute of Translators and Interpreters (WAITI). As the first and only degree of its kind in the state, the UWA Master of Translation has been welcomed by the professional community. In this context, job prospects for qualified translators are bright, and potential hosts for work placements numerous, be they migration and translation agencies, large corporations, small businesses, educational institutions, or the press. However, the local economy is also heavily impacted by 'crash and burn' cycles: when China sneezes, Western Australia catches a cold. More importantly businesses, like agencies and consultancies, our main source of work placement hosts, are born and die every day.

Finding solid partners offering good work placement conditions, long term collaboration, and worthy job prospects is therefore a delicate task. At UWA this task is entrusted to an academic coordinator, this article's author, with a long experience in both commercial and literary translations. She has been on one of NAATI's examiners panel for more than 25 years, an advantage when dealing with this complex organization, and maintains close contacts with national and local professional organizations. She was instrumental in setting the Master of Translation, drawing on Europe's long experience in training translators in the higher education sector, and getting acquainted with the educational landscape at Chinese universities listed in the 211 and 985 ministerial projects. She is involved in articulation agreements with Chinese partner universities, which offer opportunities for China-Australia double badged-degrees. UWA recently joined the Australian University Translation \& Interpreting Forum (AUTIF), a consortium of Translation programs offered in the Australian tertiary education sector, which shares resources and acts as a benchmarking group on course delivery and research.

Owing to the close economic and educational links with China, it will come as no surprise that a large proportion of UWA international students come from China, either as undergraduates or postgraduates. Consequently, the Chinese stream of the Master of Translation Studies is the largest of the four language specializations on offer in the degree. For this reason I have chosen to examine four work placements out of five involving Chinese students, as they are representative of our cohort and are destined to fill a local and international demand for qualified translators in the language pair English/Chinese. The fifth case study concerns an Australian student in the English>French language pair.

\section{Work placements: Five Case Studies}

\section{Case study 1: Ms. Cheng ${ }^{11}$}

Drawing on her personal connection with the CEO of Xi'Ao, an education and migration consultancy operating in Perth since 1999, Ms. Cheng prearranged her own placement. After discussing with the CEO and the subject coordinator, a contract 
was signed with the consultancy, whereby Ms. Chen would do a full-time, unpaid internship. The company of about 20 staff is divided into an immigration department and an education department, focusing on international education joint programs with China and migration visa services to Chinese students but also workers and business people. Given the broad range of services that Xi'Ao provides there is a large amount of translation to be done, mostly from Chinese into English.

Ms. Cheng was assigned large Chinese documents to translate into English in fields she was unfamiliar with, and was given no prior advice or sample translations, let alone training. The weekly in-house professional development sessions were of a general nature, rather than translation related. Even though the Master trains in both directions, as a native speaker of Chinese, her strongest skills are in the English into Chinese direction, but the bulk of her assignments was in her less proficient direction. When given an assignment she was not told what the timeframe was, and felt it had to be done as quickly as possible. Formatting of the target document was also deemed important, and the student found it distracted from her main focus on translation quality. Her line manager at Xi'Ao was moderately helpful, being very busy herself, although she made sure the draft translations were thoroughly checked. Time pressure and lack of preparation meant the work submitted was not of the highest quality, and the supervisor remarked on the amount of corrections to be made, and how time-consuming it was. Ms. Cheng felt that the criticism was not constructive and did not help with subsequent translations. The student was also distressed when she spent several days translating a document only to be told that she had been given a discarded draft version. She also received conflicting advice regarding a technical document that was badly written and repetitive: one colleague advised her to translate it as is, the other suggested she rewrite the original. Although some tenets of AUSIT Code of Ethics were adhered to - confidentiality, conflict of interest - the finer points of professional ethics such as accuracy, competency, and clarity of work boundaries were routinely overlooked. Cheng's work supervisor was NAATI accredited, but none of her colleagues directly involved in translation were qualified translators. Her professional ethics was constantly challenged, as she was not able to turn down a translation for which she did not have the expertise or make personal decisions on altering the original document.

Neither the line manager nor the team members had any notion of computeraided translation tools - in fact one of them was in the habit of handwriting all her translations, so the workflow was inefficient, and despite working in only two fields, education and immigration, no effort at creating translation memories and standardizing the terminology had ever been made. For confidentiality reasons Ms. Cheng was not allowed to use her own computer complete with glossaries and translation memories she had built up during her studies. Despite being a proficient user of SDL Trados, she could not make use of it during her placement.

It is clear that Ms. Cheng was confronted with very common issues translators face in the workplace but lacked the confidence and experience to deal with them. She did not have the gumption to ask questions about deadlines for instance or organize a more efficient workflow, nor get the translation team to adopt computer-aided translation tools. Nobody was interested in her 'new ideas.' Her inability to transfer her theoretical knowledge into practical skills, her linguistic weaknesses and limited opportunities to exercise her professional code of conduct made this experience 
distressing. Ms. Cheng remained professional in her dealings with the company but documented her frustrations in her reflective essay. Her conclusion was that she was not cut out to become a full-time translator. She supposed that working part-time would buy her the time she needed to submit quality work. Somewhat paradoxically, this outcome is a major benefit of the work placement: the student did find out what her ideal professional setting should be.

In contrast to the student's experience, her line manager wrote a glowing report, ticking 'outstanding' in the evaluation sheet for skills, reliability, autonomy, and professional conduct. No free comment was added. The report was obviously hastily drawn-up just to satisfy the contractual requirements and proved inadequate as a component of the assessment. Although the work placement was seen as valuable by the consultancy's CEO, the person in charge of the intern did not as it was an added duty in an otherwise heavy work schedule. The company did not realize that the work supervisor would need extra time to oversee the intern's training, hence the lack of genuine commitment.

For Ms. Cheng's university coordinator, the take-home lesson is in future to be an active participant to early conversations about the actual translation assignments and duties to support the intern in the work place. In other words, it is the responsibility of the subject coordinator to make sure the work environment model is tempered by a learning environment model. Students have to be better prepared for real-life situations such as work being corrected, criticized, or extensively reviewed. In turn, the hosts' demands have to adjust to the intern's competencies and needs. Further, in case of inadequate matching between hosts' and students' expectations, the placement contract contains exit clauses which students are guaranteed they can action without academic penalty. Again, the student was paralyzed by her inexperience and working with an older Chinese line manager.

\section{Case Study 2: Ms. Wang}

Ms. Wang did not need any assistance in finding her host either. Mr. Xin, the CEO of Xinxin, a recently established translation company specialized in the resource sector and associated industries as well as a provider of Chinese language classes, gave a talk to the Masters students about Translation agencies in Perth, and expressed interest in hosting an intern. Ms. Wang sent her CV and after initial discussions, it was agreed she would do a full-time work placement at the agency. The CEO himself would be her line manager, allocating tasks and reviewing them himself. He would come to the office specifically to look after her, his other staff working from home and only coming for weekly staff meetings or consultations with clients. One positive aspect of this work placement was that Ms. Wang observed direct dealings with clients, from submissions of projects through quotes to project completions.

Although there was no pre-training session, the CEO gave precise and detailed instructions for each of the three major projects Ms. Wang was entrusted with. He provided sample translations, and asked Ms. Wang to translate short extracts which he checked before assigning the full documents. Each project was of an increasing difficulty - a mining report, marketing material for skin products, and, lastly the localization of an entire website - showing that Mr. Xin had given some thought to what would be of most value to his company and the trainee alike. He also gave 
Ms. Wang more and more autonomy in carrying the projects as the weeks went by. This type of scaffolding might be a pedagogical skill Mr. Xin acquired in the teaching arm of his business.

Ms. Wang was able to build temporary translation memories based on mining industry journals, and on magazines on cosmetics; her research prior to doing the actual translation included trawling the Internet for websites on the relevant subject areas. In her reflective piece Ms. Wang expressed a feeling of achievement and an increased confidence. Recognition of the quality of her work came in the form of an offer for a paid assignment from a client of Xinxin's. Before accepting, she asked, and was granted, Mr. Xin's approval.

Her reflective report however contained dubious statements:

the most important thing is to have faith in ourselves and build up our confidence. Because in the workplace, a positive attitude and courage are assets for building up one's own customer base and guaranteeing a long-term cooperation for business.

“The most important thing" is to fill one's knowledge gap, do preparatory work (like building terminology and word memory) or turn to experts for explanations. Justified confidence will follow. "A positive attitude and courage" certainly matter, but much less than well-grounded expertise: a confident, positive and courageous translator might be a wretched translator. It was interesting to see that even a positive work experience could be interpreted wrongly.

The host's evaluation report was extremely positive. Mr. Xin wrote a long paragraph of nuanced and constructive comments, concluding: "we look forward to our cooperation with her in the near future." Ms. Wang completed her degree late 2015 and is now on the books of the agency as a fully-fledged translator. This represents the most ideal outcome of a work placement as well as recognition of the quality of the degree.

\section{Case Study 3: Mr. Li}

Mr. Li could not secure an internship on his own, so he was placed within the Faculty's marketing service. Many Faculty marketing managers at UWA have regularly expressed a desire to host Chinese translation interns in order to produce - at no cost - promotional material targeting Chinese university partners and agents, students and their parents. There are drawbacks to such placements as they do not lead to employment opportunities, and do not provide an insight into commercial businesses or agencies' environments. However, the placement was appropriate for Mr. Li, who had an interest in marketing and education. The marketing service is part of the Arts Faculty Dean's office, so he was keen to see from the inside how his faculty operated.

The other major difference with Mr. Li's placement was that he was put in a monolingual working environment where nobody had any knowledge of Chinese or translation issues, such as the notion that some texts might be too hard for the trainee to translate, and that a quality control process was necessary. The subject coordinator ended up being the linguistic and professional expert who was in charge of reviewing all translations done by $\mathrm{Mr}$. Li, a fairly onerous task. Mr. Li's line manager has had experience in supervising public relations and marketing interns before, so she knew that the time she would devote to the trainee's preparation and instructions 
would pay off in the end. She preferred a part-time work placement as she herself had deadlines to meet on other projects and would not be able to supervise non-stop for three weeks. Mr. Li was happy to comply.

In his reflective report Mr. Li stressed that although he was an international student, he had never carried out a thorough comparison of the education systems in China and Australia. He had to learn the difference between diplomas and certificates, a faculty, a Department and a Discipline, and consider the distinctive distribution of disciplines within Arts Faculties in the two countries. This increased knowledge, he believed, would look good on his CV.

His most important contribution was to suggest changes to the original brochures and posters in English: he knew the target audience well and felt the way the information was presented needed to be modified and some information revised, omitted or added. He was a believer of Katharina Reiss' text typology (1981), and adept in Lawrence Venuti's target-oriented methodologies (1995). As informative and operative types of texts, promotional material had to be domesticated in order to be attractive. Yet foreignization - such as leaving the English term in the Chinese target text - was also a possibility for the occasional English word like 'iGeneration' if it sounded catchy. His approach to website localization was also grounded in theory which a marketing manager would not know about or express in the same way.

In retrospect Mr. Li was disappointed he did not invest time in building terminology memories to achieve coherence in his translations. He also admitted to not trying to use SDL Trados even though this was available to him through the University's license. It was a missed opportunity to develop his skills in a translation tool widely used by the industry.

As in the other case studies above, the host evaluation was "outstanding" on all criteria, and the general statement worded as a job reference rather than a genuine commentary.

The placement within the university environment made it easy for the subject coordinator to remain in close proximity to the intern, and iron out any problems when they arose. Again Mr. Li was unprepared for the amount of corrections his translations needed to undergo. The resulting brochures and websites in Chinese were however greatly praised by faculty executives and student recruitment agents. The promotional material in Chinese is now part of packages given to Chinese delegations coming to the campus, and when visiting partner universities in China, a fact that was relayed to the student on many occasions. Although he remains the typical invisible translator Venuti (1995) has theorized, Mr. Li is proud of having contributed to the marketing of his faculty.

\section{Case Study 4: Ms. Fu}

The last case study for a Chinese intern is that of Ms. Fu's placement with the Confucius Institute of Perth (CIP). A few things are worth highlighting about the CIP. Founded ten years ago, it was the first Confucius Institute in the country: the choice of Perth over a larger Australian capital city located in the eastern seaboard is testament to the long-standing China-Western Australia connections. Equally significant is the fact that the CIP was established as an arm of UWA, with the CIP director being an academic with teaching and research responsibilities at the University. 
Ms. Fu specifically requested to work at the CI due to the prestige attached to the Institute ("a stint with CI at UWA would certainly boost my CV regardless which country I choose to settle in to advance my translation career," she wrote in her report), and its emphasis on education, a field with substantial and as-yet-unmet demand for translation. For its part the CIP, which employs only Chinese nationals, none of them NAATI accredited, was keen to host a translation trainee who would be proficient in both Chinese and English. Ms. Fu's quasi-bilingualism and outstanding academic record made her the ideal candidate.

Assigned translations of a variety of text types, Ms. Fu was able to make use of SDL Trados, finding it an ideal tool for segmenting, formatting and of course building a substantial translation memory. The largest project Ms. Fu was tasked with was the translation of a Chinese language textbook aimed at Western Australian primary and secondary students. She explains in her report that she made the macro-decision of domesticating the Chinese original, so that "the [English] translated text was as fluent and idiomatic as possible to increase engagement and to maintain [the model readers,' i.e. young readers'] interest towards learning." However, there were instances where foreignization was required as in the translation of realia (objects from real life) for fear of "creating a false impression that the Chinese culture is very similar to the local culture." Yet Ms. Fu also mentioned instances of mid-way strategies:

As for the semi-operative text, its primary function is to persuade and convince readers to take an action. Therefore, I prioritized readers' receptivity and took on an "adaptive method" where I replaced some words to ensure that the language convention was well adjusted to the expectations of the Chinese readers, which made it more appealing than a mere literal translation.

She concluded by expanding on the notion of "acquired intuition," whereby translators do not have the luxury of checking every single utterance nor of a cooling period before final submission. They must make a leap of faith based on their intuition and experience. This is built or 'acquired' over time.

I have reproduced her comments at length as they are much more sophisticated than any other trainees' reflections. It is clear that the student has a mature and fine grasp of theoretical issues and their application to real life situations: she demonstrates excellent learning transfer capabilities. If anything, Ms. Fu was disappointed that the duration for the compulsory placement was so short. This is the reason why Ms. Fu still works at the CIP on a part-time, voluntary basis, gaining more experience and expanding her network. Her work placement consolidated her formal university education and confirmed her choice of career.

It can be predicted with certainty that students with such clear and determined career paths - and excellent language and translation abilities - are likely to make the work placement a successful experience for all concerned. The work supervisor's report was very complimentary, praising in particular her mature approach to work, including asking for clarification when it was needed, taking initiatives, and meeting deadlines. The work coordinator was evidently committed to making the internship work for the CIP and the trainee. 


\section{Case study 5: Ms. White}

From the start of her studies Ms. White had planned to do her internship in France or a French-speaking country in order to explore work opportunities and benefit from a linguistic immersion. Despite contacting many potential hosts in France, she didn't manage to secure a placement. It turns out that the short duration of the placement did not fit with French companies' culture of hosting interns for six months or more. Eventually, after hearing that a non-governmental organization, Environment Protection Surveillance (EPS) based in New Caledonia was keen to take Australian interns in their Translation Department, Ms. White approached ESP and was offered a 3-week full-time placement. ESP's mission is to foster the wellbeing of peoples living in 26 Pacific Island countries through scientific and technical knowledge.

Most of ESP's documents are in English and have to be translated into French, but there is a small number of technical documents in French, particularly on fisheries, whose translation into English ESP needed to be checked. Being the most natural direction for Ms. White, her work supervisor entrusted her in the first week of placement with revising those existing translations. This gave the intern time to familiarize herself with a new field and the MultiTrans database the organization uses to store their translations. The following weeks, her training was deemed complete and Ms. White was allowed to translate documents whose "subject areas ranged from sea cucumbers to waste disposal and rebuilding in Wallis and Futuna."

Her reflective report focussed on two points. Firstly, like Mr. Li above, the intern asked herself about the target readership of her translations, which could be either the general public interested in ESP's activities, or their specialist staff. She had to adapt her work accordingly:

This was a significant issue for me when translating a text on sea cucumbers and gastropods: if this was for the general public, then I would need to use words like 'seed coat' instead of 'tegument' or 'daytime / night-time' instead of 'diurne / nocturne.' The text however was for ESP scientists with English as their L1. Subsequently, I kept the text as 'scientifically intelligent' as possible by keeping words in their original forms and opting for scientific terms over generic terms e.g.: 'genera' instead of 'kind / sort / class / division' and 'evisceration' instead of 'cutting.'

Secondly, the Department has built over the years an impressive terminology memory, and most of the time, the intern used it extensively to find appropriate and recognized equivalent terms. However, she felt in some instances her own choice to be more felicitous. Here is the example she included in her report:

Towards the end of my internship, I asked [the work supervisor] about the term 'boisement.' After consulting the termbase we discovered that sometimes the same word was used for 'reforestation' and 'afforestation,' two terms with different meanings. I made a 'cheat sheet' to define afforestation, deforestation and reforestation. Other translators and interpreters in the Department found the clarification most helpful.

She took many initiatives of this nature and established strong lines of communication with her colleagues. Interestingly, her line manager did not remark favourably on this, finding that her frequent enquiries and interruptions impacted on everyone's efficiency, and suggesting this accounted for Ms. White's difficulty in abiding by deadlines. Here is the concluding statement of her evaluation report: "[Ms. White's] 
working style is a bit eclectic, which might be a problem in a more driven translation setting with an agency or as a freelance." It was also noted that the placement was too short, confirming French-speaking organizations' usual expectations as did our previous intern, Ms. Fu, who also felt a need for a longer placement to make the most of the experience.

\section{Conclusion}

Lessons from the five case studies are clear: placements should be longer than three weeks, and six week-placements (240 hours) are now the rule at UWA for Master of Translation students. Another finding is that more involvement and commitment from the two supervisors are prerequisites to a successful work placement. What the literature doesn't mention is that translation academics are usually not trained as supervisors and coordinators of work placements. In light of this, they could draw on various practicum coordinators in Arts faculties, Business and Engineering faculties. They could also learn much from their counterparts in vocational courses like nursing and library studies, who have a long experience in running apprenticeships and work placements.

Responsibilities for the subject coordinator start early in the process: in the classroom in fact, when delivering units on professional conduct like at UWA and other higher education institutions. Even though students are trained in ethics, ultimately, subject coordinators are the ones responsible for preventing unethical practices being imposed by the hosts. No intern was requested to churn out translation after translation like 'contemporary slaves' (see note 6). However, in Case study 1, the lack of communication and understanding led to violations of the AUSIT Code of Ethics in at least two principles, namely, competency and accuracy. One of the most important tasks of any translation graduate program is to "train students to develop the ability to act ethically in the real world" (Ko and Chen 2015: 335). Work placements ought to act as ideal conduits for the transfer of ethical knowledge.

Even when students find their own placements, the coordinator must ensure a good fit between all parties' expectations. Preparing the students could also involve sending them to the workplace for a short time before the actual placement to observe and understand the work culture. This would be an opportunity to understand practical issues such as how confidentiality is maintained and whether translation tools can be used, and personal computers brought to the office. Students should provide a short description of their expectations and goals ahead of the placement. Most students are aware that a work experience is an opportunity to increase their 'capitals.' As Pym (2013: 18) notes, Pierre Bourdieu's economic, social, symbolic and cultural capitals are all actioned during work placements. In all five cases students increased their social capital through networking, as well as their symbolic capital - "it will look good on my CV," as in case studies 3 and 4. Cultural capital in the form of expanded language and translation skills increased too, as Mr. Li commented about his increased knowledge of the education field. This is mentioned at length in the diaries: “I translated," Ms. Fu writes, “'agent' as 经纪人 [used in Singapore]. However, since I am aware that this document was specifically targeting Mainland Chinese readers, I had to use an alternative term; therefore, I settled for 代理商 instead.” Ms. White's diary too mentions educating her flair about language: 
One thing I have noticed in my internship is how frequently certain phrases occur. One such phrase is the use of "permettre." Literally it means to permit or allow but in conjunction with other verbs, its purpose is to allow or enable. Translated literally "devrait permettre d'identifier" would mean "should allow identification of," but in the text I am translating "illustrate" is the best equivalent.

Finally, although not paid, their work placement may bring economic advantage in the future (as in Case 2). So, as a way to equip and prepare interns better, they could be asked to frame their plan for the work placement in terms of increasing their 'capitals.'

Subject coordinators must also 'prepare' the host. With their knowledge of students' strengths and weaknesses, subject coordinators are in a position to clarify role boundaries such as levels of textual difficulties a student is able to tackle, and in which language direction.

The way to assess work placements is to rely on self-reporting by the students, a common practice as mentioned above. Submitting assignments, whether online like e-portfolios ${ }^{12}$ or not, does not change the fundamental nature of the selfreporting and its limitations in terms of breadth and depth. Despite being difficult to integrate into the assessment, company evaluations are also essential. Yet line managers are no pedagogues and are often poorly skilled in assessment procedures. These evaluations become in effect a 'failed component': a proof of attendance and good behaviour rather than quality. They are indispensable but cannot be used for a final grade, hence the practice of granting credit for work placements on a pass/ fail basis rather than a grade. Nonetheless a truthful evaluation was wanting in all the above cases bar one: the four Chinese students received the same type of evaluation even though their capabilities and performances differed greatly. There might be a cultural approach to evaluation. The French-speaking organization had more experience in hosting students, and a culture of straightforward communication. Post-placement, face-to-face informal meetings with work supervisors might be a way of eliciting more genuine appraisals - and an opportunity to express thanks to hosts.

Assessment is both retrospective and predictive: it is assumed that a successful work placement is a predictor for the production of a good translator. Is it a predictor for better performance in their studies? With a work placement taken in the middle of their two-year studies, it remains to be seen if John Duignan's disenchanted conclusion about undergraduate placements in business studies applies also to postgraduate work placements in translation:

the qualities that are required for successful performance in the placement domain and the skills and competencies that are engendered by successful placements are not easily translatable into academic performance. (Duignan 2013: 345)

My main concern, like most researchers, has been about knowledge transfer from the classroom into the workplace. Is it asking too much to expect learning transfer from the workplace into the classroom? Is the ideal structure a collapsing of the divide between the learning environment and work environment models, guided by the same lifelong learning and ethical principles? 


\section{NOTES}

1. Creative Skillset (2012): Guidelines for employers offering work placement schemes in the Creative Industries. Visited 21 July 2016, <https://creativeskillset.org/assets/0000/6234/ Guidelines_for_employers_offering_work_placements_in_the_Creative_Industries.pdf $>$.

2. Australia Collaborative Education Network (2015): National Strategy on Work Integrated Learning in University Education. Australia Collaborative Education Network (ACEN). Visited 12 June 2018, <http://cdn1.acen.edu.au/ wp-content/uploads/2015/03/National-WIL-Strategy-inuniversity-education-032015.pdf >.

3. Blanc, Quentin (10 March 2013): Les secteurs qui abusent des stagiaires. Le Figaro Étudiant. Visited 25 June 2016, <http://etudiant.lefigaro.fr/orientation/actus-et-conseils/detail/article/lessecteurs-qui-abusent-des- stagiaires-1396/>.

4. KreissL, Brian (28 February 2012): The ethics of internships and unpaid work placements. U.K. work experience controversy highlights ethical dilemma for employers. Canadian HR Reporter. Visited 31 January 2018, <https:// www.hrreporter.com/sharedwidgets/systools/_printpost_. aspx?articleid $=448>$.

5. Coventry, Petrina (18 February 2016): Despite the bad press ethical internships are possible. The Ethic Centre. Visited 7 June 2016, <http://www.ethics.org.au/on-ethics/blog/february-2016/despitethe-bad-press,-ethical- internships-are-pos $>$.

6. Sebus (25 June 2007): Le stagiaire, esclave contemporain. Agoravox. Visited 30 June 2016, <https:// www.agoravox.fr/tribune-libre/article/le-stagiaire-esclave-contemporain-26163>.

7. Souffi, Emmanuelle (25 January 2016): Les stagiaires exploités des grandes institutions. Liaisons Sociales Magazine. Visited 15 June 2016, <http://www.wk-rh.fr/actualites/detail/90797/les-stagiaires-exploites-des- grandes-institutions-.html >.

8. See for instance, Charles Stuart University's Professional Placement guidelines. Visited 26 June 2016, <https://www.csu.edu.au/faculty/educat/sis/professional-experience/placement/host/hostguidelines $>$.

9. Australian Institute of Interpreters and Translators (2012): Code of Ethics. Australian Institute of Interpreters and Translators (AUSIT). Visited 3 June 2016, <http://ausit.org/AUSIT/ About/Ethics_Conduct/Code_of_Ethics/ AUSIT/About/Code_of_Ethics.aspx $>$.

10. Australia China Business Council (13 April 2016): ACBC Western Australia. Visited 14 July 2016, <http://www.acbc.com.au/western-australia $>$.

11. For confidentiality purposes, all names of students, work supervisors and companies have been modified.

12. Simmons, Catherine, Williams, Anthony, Sher, Williams and Levett-Jones, Tracy, eds. (2012): Work Ready. E- portfolios to Support Professional Placements. Sydney: Australian Government Office for Learning and Teaching.

\section{REFERENCES}

Duignan, John (2003): Placement and adding value to the academic performance of undergraduates: reconfiguring the architecture, an empirical investigation. Journal of Vocational Education and Training. 55(3):335-345.

El Maghnougi, Naima (2014): The Turns of Translation Studies: Different Histories, Shifting Discourses. Dragoman Journal, Arabic Translators International, ATI, 4 July 2014.

Gouadec, Daniel (2007): Translation as a Profession. Amsterdam/Philadelphia: Benjamins Publishing Company.

Ko, Leong and Chen, Ping, eds. (2015): Translation and Cross-cultural communication studies in the Asia Pacific. Leiden/Boston: Rodopi.

Orlando, Marc (2012): Training of Professional Translators in Australia: Process-Oriented and Product-Oriented Evaluation Approaches. In: Séverine Hubscher-Davidson and Michal Bonodo, eds. Global Trends in Translator and Interpreter Training Mediation and Culture. New York: Bloomsbury, Continuum, 197-216.

Pym, Anthony, Gonzalez-Núñez, Gabriel, Miquel-Iriarte, Marta, et al. (2013): Work placements in doctoral research training in the humanities: Eight cases from translation studies. Across Languages and Cultures. 15(1):1-23. 
ReIss, Katharina (1981): Type, kind and individuality of text: decision making in translation. Poetics Today. 2(4):121-131.

Venuti, Lawrence (1995): The Translator's Invisibility: A History of Translation. London/New York: Routledge.

Vriens, Mariet, Op de Beeck, Ilse, De Gruyter, Johannes, et al. (2010): Virtual placements: improving the international work experience of students. In: Louis Gómez Chova, David Martí Belenguer, and Ignacio Candel Torres, eds. EDUlearn10 Proceedings. $\left(2^{\text {nd }}\right.$ International Conference on Education and New Learning Technologies, Barcelona, 5-7 July 2010). Valencia: International Association of Technology, Education and Development (IATED), 1175-1183. Visited 16 June 2016, <https://www.academia.edu/30271756/ Virtual_placements_improving_the_international_work_experience_of_students $>$. 